\title{
Simultaneous determination of warfarin and 7-hydroxywarfarin in rat plasma by HPLC-FLD
}

\author{
AREF ZAYED ${ }^{1, *}$ \\ WAHBY M. BABARESH ${ }^{1}$ \\ RUBA S. DARWEESH ${ }^{2}$ \\ TAMAM EL-ELIMAT ${ }^{1}$ \\ ${ }^{1}$ Department of Medicinal Chemistry \\ and Pharmacognosy \\ Faculty of Pharmacy, Jordan University \\ of Science and Technology \\ Irbid 22110, Jordan

\section{${ }^{2}$ Department of Pharmaceutical Technology \\ Faculty of Pharmacy, Jordan University of Science and Technology \\ Irbid 22110, Jordan}

\begin{abstract}
In this study, high-performance liquid chromatography with fluorescence detection (HPLC-FLD) has been used for the first time, for direct determination of warfarin and its major metabolite, 7-hydroxywarfarin, in rat plasma. The simple and sensitive method was developed using Fortis ${ }^{\circledR}$ reversed-phase diphenyl column $(150 \times 4.6 \mathrm{~mm}, 3 \mu \mathrm{m})$ and a mobile phase composed of phosphate buffer $\left(25 \mathrm{mmol} \mathrm{L}^{-1}\right) /$ methanol/acetonitrile (70:20:10, $V / V / V)$, adjusted to $\mathrm{pH} 7.4$,

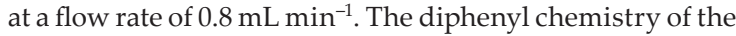
stationary phase provided a unique selectivity for separating the structurally related aromatic analytes, warfarin and 7-hydroxywarfarin, allowing their successful quantification in the complex plasma matrix. The method was linear over the range $0.01-25 \mu \mathrm{gL}^{-1}$, for warfarin and 7-hydroxywarfarin, and was found to be accurate, precise and selective in accordance with US FDA guidance for bioanalytical method validation. The method was sensitive enough to quantify $0.01 \mu \mathrm{g} \mathrm{mL}-1$ of warfarin and 7-hydroxywarfarin (LLOQ) using only $100 \mu \mathrm{L}$ of plasma. The applicability of this method was demonstrated by analyzing samples obtained from rats after oral administration of a single warfarin dose, and studying warfarin and 7-hydroxywarfarin pharmacokinetics.
\end{abstract}

Keywords: warfarin, 7-hydroxywarfarin, high-performance liquid chromatography-fluorescence detection, rat plasma, pharmacokinetics

Warfarin is the most commonly prescribed anticoagulant in the world (1). It is a vitamin $\mathrm{K}$ antagonist used to treat and prevent blood clots and is indicated for the treatment of atrial fibrillation and deep vein thrombosis (2). Warfarin is a racemic mixture of 3 - $(\alpha$-acetonylbenzyl)-4-hydroxycoumarin (Fig. 1). The $S$-enantiomer exhibits $2-5$ times higher anticoagulant activity than the $R$-enantiomer in humans (3-5). It is absorbed rapidly from gastrointestinal tract following oral administration, reaching peak plasma concentration

\footnotetext{
*Correspondence; e-mail address: alzayed@just.edu.jo
} 


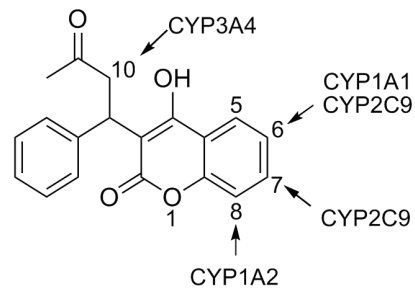

Fig. 1. Warfarin structure showing hydroxylation sites by cytochrome P450.

after $4 \mathrm{~h}(5,6)$. The effective half-life after oral administration ranges from 20 to $60 \mathrm{~h}$ with $92 \%$ of the dose excreted in the urine. The half-life of the $R$-enantiomer is longer $(37-89 \mathrm{~h})$ than that of the $S$-enantiomer $(21-43 \mathrm{~h})(6)$. The two enantiomers are stereoselectively metabolized by hepatic CYP450 microsomal enzymes (7). $S$-warfarin metabolism by CYP2C9 yields 6- and 7-hydroxylated metabolites, whereas $R$-warfarin metabolism by CYP1A1, 1A2 and 3A4 yields 6-, 8-, and 10-hydroxylated metabolites (8-10) (Fig. 1). Overall, 7-hydroxywarfarin is the most predominant metabolite of warfarin in humans (11-13). Several studies indicated that alteration of warfarin pharmacokinetics (PK) following the administration of CYP450 inhibitors can enhance the anticoagulant activity and thus increase the risk of bleeding as a result of elevation of warfarin plasma concentration $(14,15)$. The likelihood of such interaction is further increased due to the narrow therapeutic index and extensive protein binding (99.83\%) of warfarin (1), in addition to the significant inter-individual variation in drug response. Determination of metabolic ratios of warfarin/7-hydroxywarfarin can provide valuable information about potential interaction of warfarin with drugs or diet at the metabolic level where many warfarin interactions occur. To investigate these interactions, sensitive and selective methods are required for the simultaneous quantification of warfarin and its 7-hydroxywarfarin metabolite in plasma.

Various methods have been reported for the quantitation of racemic warfarin and its main metabolites in biological samples using high-performance liquid chromatography (HPLC) coupled with a variety of detectors including ultraviolet (UV) (16-19), fluorescence (FLD) (19-21) and mass spectrometric detector (MS) (13, 22-26). Although LC-MS/MS methods are very selective and sensitive, the high capital cost of the MS detector presents a major limitation. HPLC-UV is a cheaper option, but it lacks the sensitivity and selectivity required for the analysis of the low plasma levels of warfarin and its metabolites. The inherited selectivity and sensitivity of fluorescence detector were exploited in few studies for the measurement of warfarin and its hydroxylated metabolites in biological samples including urine (19), plasma (20) and microbial cultures (27). Takahashi et al. (19) quantified warfarin in human plasma or 7-hydroxywarfarin in urine by HPLC with UV or fluorescent detection. Lomonaco et al. (20) developed and validated HPLC-FLD method for simultaneous quantification of warfarin and warfarin alcohols (ketone warfarin). Using post-column $\mathrm{pH}$ switching, Lee et al. (28) used a normal phase HPLC-FLD method for quantifying racemic warfarin and its major metabolites in plasma. None of the previously described HPLC-FLD methods, however, allowed for direct and simultaneous quantification of warfarin and 7-hydroxywarfarin in plasma. 
In this study, we describe the development and validation of the first HPLC-FLD method for simultaneous and direct determination of warfarin and 7-hydroxywarfarin in in vivo small samples $(100 \mu \mathrm{L})$ of rat plasma. Unlike other HPLC-FLD methods, the samples didn't require sample derivatization or post-column manipulation to detect warfarin and 7-hydroxywarfarin in plasma, which is a major advantage for the routine analysis of biological samples. The method was applied successfully to assess the PK of warfarin in rats following oral administration of a single warfarin dose.

\section{EXPERIMENTAL}

\section{Materials}

Racemic warfarin, 7-hydroxywarfarin and 10-hydroxywarfarin were purchased from Sigma-Aldrich (USA). 4-Hydroxywarfarin, 6-hydroxywarfarin and warfarin alcohol were purchased from Toronto Research Chemicals (Canada). Naproxen (purity $99.2 \%$ ) was kindly supplied as a gift from Hikma Pharmaceuticals (Jordan). HPLC grade acetonitrile, ethylacetate and methanol were purchased from Fisher Scientific (USA). Phosphate buffer, potassium monobasic and dibasic, were purchased from Sigma-Aldrich.

\section{Preparation of standard solutions}

A stock solution of each warfarin and 7-hydroxywarfarin was prepared by dissolving $5.0 \mathrm{mg}$ of the reference standard in $10 \mathrm{~mL}$ methanol in a volumetric flask to produce a concentration of $500 \mu \mathrm{g} \mathrm{mL} \mathrm{m}^{-1}$. Working solution $\left(50.0 \mu \mathrm{g} \mathrm{mL}^{-1}\right)$ of each, warfarin and 7-hydroxywarfarin, was prepared in methanol after dilution. A stock solution of naproxen, used as an internal standard, was prepared by dissolving $5.0 \mathrm{mg}$ of naproxen in $25 \mathrm{~mL}$ methanol to produce a concentration of $200 \mu \mathrm{g} \mathrm{mL} \mathrm{m}^{-1}$.

The working solutions were used to prepare eight plasma calibration standards within a concentration range $0.01-25 \mu \mathrm{g} \mathrm{mL} \mathrm{L}^{-1}$ for both warfarin and 7-hydroxywarfarin. Appropriate amounts of the standards were used to spike drug free plasma (blank plasma) to produce the following calibration standard concentrations: 0.01, 0.05, 0.10, 0.50, 1.0, 5.0, 10.0 and $25.0 \mu \mathrm{g} \mathrm{mL}^{-1}$. Quality control (QC) samples were prepared in plasma at four concentration levels for both warfarin and 7-hydroxywarfarin: $20.0 \mu \mathrm{g} \mathrm{mL}^{-1}$ (QC-high), $1.0 \mu \mathrm{g} \mathrm{mL} \mathrm{m}^{-1}$ (QC-mid), $0.05 \mu \mathrm{g} \mathrm{mL} \mathrm{m}^{-1}$ (QC-low) and $0.01 \mu \mathrm{g} \mathrm{mL} \mathrm{m}^{-1}$ (LLOQ). Calibration and quality control standards were stored in propylene tubes at $-40^{\circ} \mathrm{C}$.

\section{Instrumentation}

Quantification of warfarin and 7-hydroxywarfarin was carried out on a Shimadzu 10A VP HPLC system (Japan) equipped with fluorescence detector adjusted at excitation and emission wavelengths of $310 \mathrm{~nm}$ and $390 \mathrm{~nm}$, resp. Data acquisition and integration were performed using a Shimadzu CLASS-VP v. 6.12 software. Chromatographic separation was achieved using Fortis ${ }^{\circledR}$ reversed-phase diphenyl column $(150 \times 4.6 \mathrm{~mm}, 3 \mu \mathrm{m})$ (Fortis Technologies Ltd., UK) protected by a guard cartridge $(4.0 \times 4.6 \mathrm{~mm})$. The mobile phase consisted of phosphate buffer $\left(25 \mathrm{mmol} \mathrm{L}^{-1}\right) /$ methanol/acetonitrile $(70: 20: 10, \mathrm{~V} / \mathrm{V} / \mathrm{V})$ $(\mathrm{pH} 7.4)$ and delivered at a flow rate of $0.8 \mathrm{~mL} \mathrm{~min}^{-1}$ in the isocratic mode. 


\section{Sample preparation}

Plasma samples $(100 \mu \mathrm{L})$ containing warfarin and 7-hydroxywarfarin were spiked with internal standard solution $(20 \mu \mathrm{L})$. The samples were acidified by adding $0.05 \mathrm{~mol} \mathrm{~L}^{-1}$ acetic acid $(10 \mu \mathrm{L})$ and vortex-mixed for $30 \mathrm{~s}$ before extraction with ethylacetate $(3 \mathrm{~mL})$ for $2 \mathrm{~min}$ using a vortex-mixer. After centrifugation at $4000 \mathrm{rpm}$ for $10 \mathrm{~min}$, the upper organic phase $(2.7 \mathrm{~mL})$ was transferred into clean glass tube and evaporated under a stream of nitrogen at $40{ }^{\circ} \mathrm{C}$. The residue was then reconstituted with $150 \mu \mathrm{L}$ mobile phase and $50 \mu \mathrm{L}$ was then injected into the HPLC system for quantifying warfarin and 7-hydroxywarfarin.

\section{Method development}

During the method development, different column chemistries were tested with different mobile phase compositions to achieve a chromatographic separation suitable for simultaneous quantification of warfarin and 7-hydroxywarfarin in plasma. Water, methanol and acetonitrile in different ratios were tested as solvents in the mobile phase, with formic acid or phosphate buffer for $\mathrm{pH}$ adjustment. The stationary phases tested during method development were $\mathrm{C}_{8}, \mathrm{C}_{12}, \mathrm{C}_{18}$ and diphenyl with various particle sizes and column dimensions. The optimized method was then validated in accordance with US Food and Drug Administration guidance for bioanalytical method validation (29).

\section{Analytical method validation}

Linearity. - Linearity was evaluated by examining six calibration curves with eight non-zero concentrations of warfarin and 7-hydroxywarfarin $\left(0.01-25.0 \mu \mathrm{g} \mathrm{mL}^{-1}\right)$. Peak area ratios of warfarin or 7-hydroxywarfarin to internal standard was plotted against concentrations of warfarin and 7-hydroxywarfarin using $1 / x$ linear regression weighting factor. Coefficient of determination $\left(R^{2}\right)$ equal to or greater than 0.99 was considered as an acceptable evidence of linearity.

Accuracy and precision. - Intra-day accuracy and precision were evaluated by examining plasma samples spiked with warfarin and 7-hydroxywarfarin at four concentration levels (LLOQ: $0.01 \mu \mathrm{g} \mathrm{mL}{ }^{-1}$, QC-low: $0.05 \mu \mathrm{g} \mathrm{mL}{ }^{-1}$, QC-mid: $1.0 \mu \mathrm{g} \mathrm{mL} \mathrm{mL}^{-1}$, and QC-high: 20.0 $\left.\mu \mathrm{g} \mathrm{mL} \mathrm{L}^{-1}\right)$. The run consisted of 24 spiked samples (6 replicates for each concentration) plus calibration standard samples prepared in the same day. Inter-day accuracy and precision were assessed by examining spiked plasma samples of warfarin and 7-hydroxywarfarin at four concentration levels mentioned above, each run in six replicates, on three consecutive days.

Peak areas were calculated and analyzed against a calibration curve that was prepared alongside each batch. To calculate intra-day and inter-day accuracy, the relative error $\left(e_{\mathrm{r}}\right)$ at each QC concentration level was estimated. To calculate intra-day and inter-day precision, the relative standard deviation (RSD) at each QC concentration level was determined. $e_{\mathrm{r}}$ and RSD values within $\pm 15 \%$, not exceeding $20 \%$ for $L L O Q$, were considered as evidence of acceptable accuracy and precision, resp. (29)

Sensitivity. - Sensitivity was assessed by examining six replicates at LLOQ (0.01 $\mu \mathrm{g} \mathrm{mL} \mathrm{m}^{-1}$ ). Acceptance criteria for warfarin and 7-hydroxywarfarin were that their response 
at the $L L O Q$ should be $\geq 5$ times their response of the zero calibrator (blank sample) with $e_{r}$ and RSD $\leq 20 \%$. LLOQ was defined as the lowest non-zero standard analyte concentration on the calibration curve. Limit of detection $(L O D)$ is defined as an analyte concentration resulting in a signal-to-noise ratio of 3:1.

Selectivity. - The method selectivity is the assessment for interference by cross-reacting molecules, concomitant medications and bio-transformed species. The selectivity was assessed by analyzing blank plasma samples from six different animals to show that plasma sources did not contribute to either the analytes or the internal standard responses. Each sample was analyzed for potential interferences from endogenous substances such as endogenous matrix components, metabolites and decomposition products which should be absent at the retention time of warfarin, 7-hydroxywarfarin and the internal standard naproxen. A mixture of standard solutions containing warfarin and its main metabolites (4-, 6-, 7-, 10-hydroxywarfarin and warfarin alcohol) was used to asses if the method is able to distinguish warfarin and 7-hydroxywarfarin from other potential metabolites.

Carryover. - Carryover is the appearance of an analyte in a sample from a previous one. Impact of carryover on the accuracy of the study was assessed by injecting blank samples after a calibration standard sample with the highest concentration. Carryover in the blank sample following the high concentration standard should not be greater than $20 \%$ of $L L O Q$ and $5 \%$ for the internal standard.

QC samples were interspersed with study samples before and during processing and analysis. A batch or batches in an analytical run may be rejected if the QC samples fail to meet the acceptance criteria. The total number of QCs was at least $5 \%$ of the total samples analyzed but not less than 6 samples, whichever number is greater. Duplicate QC-low, QC-mid, and QC-high were used in all distinct processing batches within a run. Not less than $50 \%$ of QCs per level should be $\pm 15 \%$ of their nominal concentration.

Stability of warfarin and 7-hydroxywarfarin in working standards and in plasma was investigated in previous reports $(13,20,22)$.

\section{Pharmacokinetic study}

Six male Sprague-Dawley (SD) rats, weighing 150-250 g, were supplied from animal house, Jordan University of Science and Technology (JUST, Irbid, Jordan). The rats were maintained in a clean room at a temperature of $25 \pm 2{ }^{\circ} \mathrm{C}$, with a 12-h light-dark cycle and $50 \%$ relative humidity. The experiments were carried out during the light cycle. The animals were acclimatized to laboratory conditions for a week prior to beginning of the experiments, and they were provided with filtered tap water and a standard rat chow diet ad libitum. All experimental procedures were carried out under the approval by the Animal Care and Use Committee (ACUC) of Jordan University of Science and Technology.

The SD rats were fasted $12 \mathrm{~h}$ before the beginning of the experiments with access to filtered tap water ad libitum. A single dose of a warfarin solution (4 mg mL $\mathrm{m}^{-1}$ in DMSO) was administered orally to each animal at a dose of $2.0 \mathrm{mg} \mathrm{kg}^{-1}$. Blood samples (200-300 $\left.\mu \mathrm{L}\right)$ were collected from the tail instantly before warfarin treatment and at $0.5,1,2,3,4,6,8,24$, 30, 48, 54, 72, 96 and $120 \mathrm{~h}$ after warfarin treatment. Blood samples were immediately 
treated by centrifugation at 13,000 rpm for $5 \mathrm{~min}$, and $100 \mu \mathrm{L}$ plasma samples were transferred to sample tubes and kept frozen at $-80^{\circ} \mathrm{C}$ until subsequent analysis.

A non-compartmental pharmacokinetic analysis was performed using WinNonlin 5.3 software (Pharsight Co., Mountain View, CA, USA). The non-compartmental pharmacokinetic parameters determined were peak plasma concentration $\left(C_{\max }\right)$, time to reach peak plasma concentration $\left(t_{\max }\right)$, terminal half-life $\left(t_{1 / 2}\right)$, apparent total clearance $(\mathrm{CL} / \mathrm{F})$, apparent volume of distribution of terminal phase $\left(V_{\mathrm{d}} / \mathrm{F}\right)$, total area under the concentration-time curve $A U C_{0}^{\infty}$, total area under the first moment curve $\left(A U M C_{0}^{\infty}\right)$ and mean residence time $(M R T)$.

\section{RESULTS AND DISCUSSION}

\section{Method development and optimization}

In order to develop selective and sensitive chromatographic separation for determination of plasma levels of warfarin and 7-hydroxywarfarin in vivo, several issues had to be addressed. Although fluorescence detection is more selective than UV, several fluorescent species, such as some warfarin metabolites, are expected to be present in the samples, although at very low concentrations. Since most of these metabolites are isomers to the 7-hydroxy metabolite, a highly selective method is therefore critical for the separation and accurate determination of warfarin and 7-hydroxywarfarin. Moreover, other interferences coming from the complex plasma matrix should be considered during method development.

Initial method development was carried out using a short $C_{12}$ column $(30 \times 2 \mathrm{~mm}$, $4 \mu \mathrm{m}$, Synergi Max RP Phenomenex ${ }^{\circledR}$ ) and a mobile phase of different ratios of acetonitrile and water. Although several compositions of mobile phase were experimented, warfarin and 7-hydroxywarfarin peaks eluted very close to each other and at early retention times where most of the polar plasma interferents were expected to elute. Therefore, it was decided to use a more retentive $C_{18}$ stationary phase and longer column $(125 \times 4.6 \mathrm{~mm}, 5 \mathrm{~mm}$, LiChrospher Phenomenex ${ }^{\circledR}$ ) which has resulted in a better separation and retention for both analytes. However, when standards of other metabolites (4-, 6- and 10-hydroxywarfarin in addition to warfarin alcohol) and naproxen, as internal standard, were added to test the selectivity of the separation, some metabolites co-eluted with either warfarin or naproxen. Adjusting the mobile phase conditions or replacing naproxen with alternative internal standards did not produce a better separation.

In order to separate these structurally related analytes within a reasonable run time, we tried a stationary phase with different chemistry and higher selectivity for aromatic compounds like warfarin and its metabolites. Thus, a diphenyl column, with small particle size $\left(150 \times 4.6 \mathrm{~mm}, 3 \mu \mathrm{m}\right.$, Fortis $\left.{ }^{\circledR}\right)$ was tested. The phenyl-based stationary phase offers a different selectivity for aromatic compounds due to the $\pi-\pi$ interactions between the electron-rich double bonds of warfarin and metabolites and stationary phase-phenyl moieties. A successful separation of all compounds was achieved in 20-min run time, as was demonstrated by injecting a mixture of standard solution of warfarin, 7-hydroxywarfarin and naproxen in the presence of 4-, 6-, 7-, 10-hydroxywarfarin and warfarin alcohol (Fig. 2). The mobile phase used was phosphate buffer $\left(25 \mathrm{mmol} \mathrm{L}^{-1}\right) /$ methanol/acetonitrile (70:20:10, $V / V / V)(\mathrm{pH} 7.4)$ at a flow rate of $0.8 \mathrm{~mL} \mathrm{~min}^{-1}$. $\mathrm{pH}$ of the mobile phase was chosen based on 


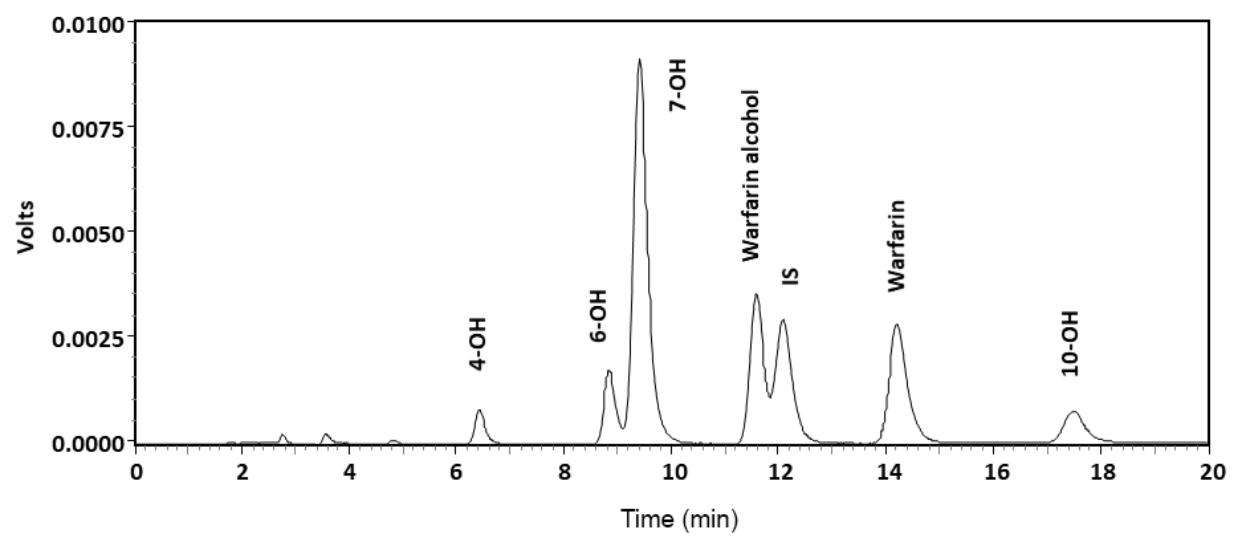

Fig. 2. Representative HPLC chromatogram for a mixture of standards of warfarin $\left(0.1 \mu \mathrm{g} \mathrm{mL}^{-1}\right)$ and its main metabolites (7-hydroxywarfarin: $0.2 \mu \mathrm{g} \mathrm{mL}^{-1}$; warfarin alcohol: $0.1 \mu \mathrm{g} \mathrm{mL}-1$; 4-, 6- and 10hydroxywarfarin: $0.05 \mu \mathrm{g} \mathrm{mL} \mathrm{m}^{-1}$ ). Keys to the peaks: 4-OH - 4-hydroxywarfarin, 6-OH - 6-hydroxywarfarin, 7-OH - 7-hydroxywarfarin, 10-OH - 10-hydroxywarfarin, IS - internal standard (naproxen).

optimization experiments, showing that acidic $\mathrm{pH}$ negatively affected the intensity of the fluorescence signal of warfarin and thus $\mathrm{pH} 7.4$ was selected as an optimum $\mathrm{pH}$. Table I gives chromatographic parameters.

\section{Method validation}

Linearity. - The method was linear for warfarin and 7-hydroxywarfarin in the concentration range of $0.01-25 \mu \mathrm{g} \mathrm{mL} \mathrm{L}^{-1} \cdot R^{2}$ was 0.998 and 0.996 for warfarin and 7-hydroxywarfarin, resp. (Table II). All samples tested and analysed were well within the calibration range of the method for both warfarin and 7-hydroxywarfarin $\left(0-25 \mu \mathrm{g} \mathrm{mL} \mathrm{L}^{-1}\right)$. No dilution was required as no samples were above the ULOQ.

Accuracy and precision. - The intra-day average relative error $\left(e_{\mathrm{r}}\right)$ and RSD were 10.4 and $8.9 \%$ for warfarin, resp., and 10.5 and $7.3 \%$ for 7-hydroxywarfarin, resp. (Table II). Similarly, the inter-day average inaccuracy $\left(e_{\mathrm{r}}\right)$ and imprecision (RSD) for warfarin and 7-hydroxywarfarin were 10.1 and $2.5 \%$, and 10.7 and $4.3 \%$, resp. (Table II). See Tables III and IV for values at each QC level.

Table I. Chromatographic parameters of the HPLC method

\begin{tabular}{lcccccc}
\hline Analyte & $\begin{array}{c}\text { Tailing } \\
\text { factor }\end{array}$ & $\begin{array}{c}\text { Retention } \\
\text { time, } t_{\mathrm{R}} \\
(\mathrm{min})\end{array}$ & $\begin{array}{c}\text { Number of } \\
\text { theoretical } \\
\text { plates }(N)\end{array}$ & $\begin{array}{c}\text { Capacity } \\
\text { factor }\left(k^{\prime}\right)\end{array}$ & $\begin{array}{c}\text { Selectivity } \\
\text { factor }\end{array}$ & Resolution \\
\cline { 1 - 5 } 7-Hydroxywarfarin & 1.35 & 9.7 & 3820 & 2.33 & & 2.69 \\
Warfarin & 1.23 & 14.3 & 4592 & 3.94 & & 2.09 \\
\hline
\end{tabular}


A. Zayed et al.: Simultaneous determination of warfarin and 7-hydroxywarfarin in rat plasma by HPLC-FLD, Acta Pharm. 70 (2020) 343-357.

Table II. Model analytical parameters evaluated for the quantification of warfarin and 7-hydroxywarfarin

\begin{tabular}{llcc}
\hline Analytical performance & & Warfarin & 7-Hydroxywarfarin \\
\hline \multirow{2}{*}{ Accuracy, $e_{\mathrm{r}}(\%)$} & Intra-day & 10.4 & 10.5 \\
& Inter-day & 10.1 & 10.7 \\
Precision, RSD $(\%)$ & Intra-day & 8.9 & 7.3 \\
Calibration range $\left(\mu \mathrm{gL}^{-1}\right)$ & Inter-day & 2.5 & 4.3 \\
$R^{2}$ & & $0.01-25$ & $0.01-25$ \\
$\left.L O D(\mu \mathrm{g} \mathrm{mL})^{-1}\right)$ & $\geq 0.998$ & $\geq 0.996$ \\
$L L O Q\left(\mu \mathrm{g} \mathrm{mL}^{-1}\right)$ & 0.003 & 0.003 \\
\hline
\end{tabular}

Table III. Intra- and inter-day precision and accuracy of the method for determination of warfarin in rat plasma

\begin{tabular}{|c|c|c|c|c|c|c|c|}
\hline \multirow[b]{2}{*}{ QC level } & \multirow{2}{*}{$\begin{array}{l}\text { Nominal } \\
\text { conc. } \\
\left(\mu \mathrm{g} \mathrm{mL}^{-1}\right)\end{array}$} & \multicolumn{3}{|c|}{ Intra-day (single batch) ${ }^{\mathrm{a}}$} & \multicolumn{3}{|c|}{ Inter-day (three batches) ${ }^{\mathrm{b}}$} \\
\hline & & $\begin{array}{l}\text { Measured } \\
\text { mean conc. } \\
\left(\mu \mathrm{g} \mathrm{mL} L^{-1}\right)\end{array}$ & RSD (\%) & $\begin{array}{c}e_{\mathrm{r}} \\
(\%)\end{array}$ & $\begin{array}{l}\text { Measured } \\
\text { mean conc. } \\
\left(\mu \mathrm{g} \mathrm{mL} \mathrm{m}^{-1}\right)\end{array}$ & RSD (\%) & $\begin{array}{c}e_{\mathrm{r}} \\
(\%)\end{array}$ \\
\hline LLOQ & 0.010 & 1.19E-02 & 9.7 & 19.0 & 1.19E-02 & 4.0 & 19.0 \\
\hline QC-low & 0.050 & 5.27E-02 & 11.8 & 5.4 & 4.90E-02 & 3.1 & -2.0 \\
\hline QC-mid & 1.0 & 1.13 & 9.2 & 13.0 & 1.08 & 2.5 & 8.0 \\
\hline QC-high & 20.0 & 19.0 & 5.0 & -5.0 & 17.8 & 0.3 & -11.0 \\
\hline
\end{tabular}

${ }^{\mathrm{a}} n=6,{ }^{\mathrm{b}} n=18$

Table IV. Intra- and inter-day precision and accuracy of the method for determination of 7-hydroxywarfarin in rat plasma

\begin{tabular}{lccccccc}
\hline QC level & $\begin{array}{c}\text { Nominal } \\
\text { conc. } \\
\left(\mu \mathrm{g} \mathrm{mL}^{-1}\right)\end{array}$ & $\begin{array}{c}\text { Intra-day (single batch })^{\mathrm{a}} \\
\begin{array}{c}\text { Measured } \\
\text { mean conc. } \\
\left(\mu \mathrm{g} \mathrm{m}^{-1}\right)\end{array}\end{array}$ & RSD $(\%)$ & $\begin{array}{c}e_{\mathrm{r}} \\
(\%)\end{array}$ & $\begin{array}{c}\text { Measured } \\
\text { mean conc. } \\
\left.(\mu \mathrm{g} \mathrm{mL})^{-1}\right)\end{array}$ & RSD $(\%)$ & $\begin{array}{c}e_{\mathrm{r}} \\
(\%)\end{array}$ \\
\hline LLOQ & 0.010 & $1.19 \mathrm{E}-02$ & 8.2 & 19.0 & $1.15 \mathrm{E}-02$ & 2.2 & 15.0 \\
QC-low & 0.050 & $5.24 \mathrm{E}-02$ & 12.5 & 4.8 & $5.11 \mathrm{E}-02$ & 5.5 & 2.2 \\
QC-mid & 1.00 & 1.15 & 3.9 & 15.0 & 1.15 & 5.0 & 15.0 \\
QC-high & 20.0 & 19.3 & 4.8 & -3.5 & 18.0 & 4.6 & -10.0 \\
\hline
\end{tabular}

${ }^{\mathrm{a}} n=6,{ }^{\mathrm{b}} n=18$ 
a)

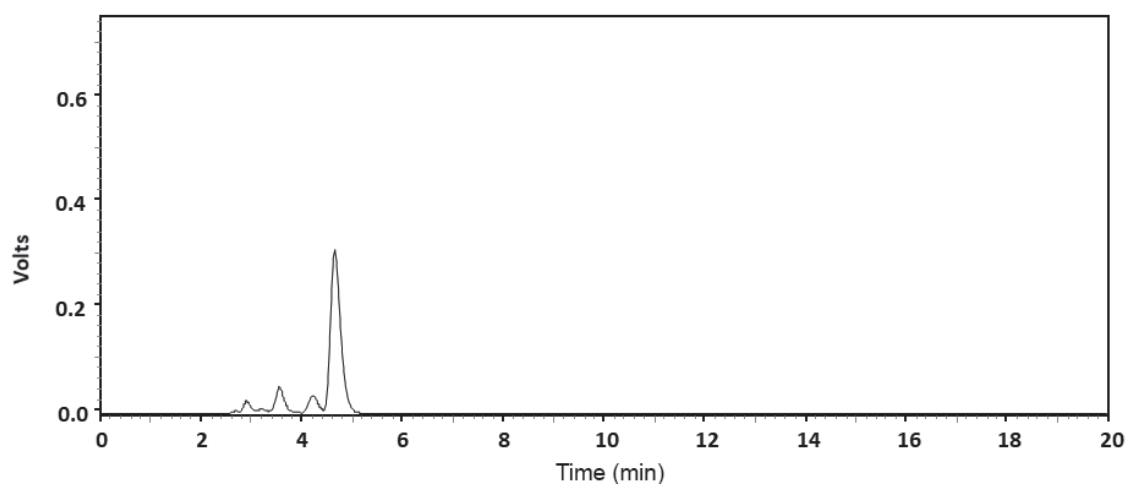

b)

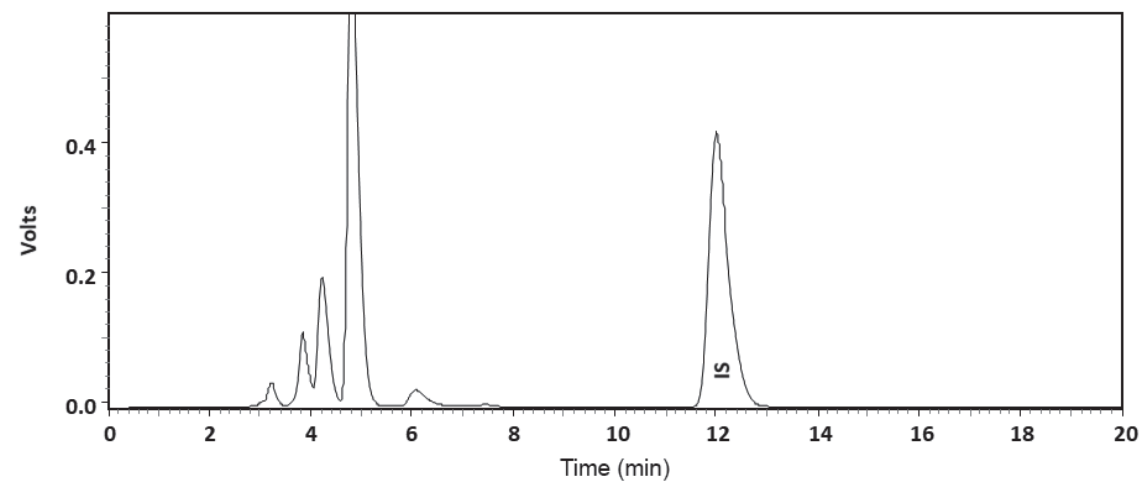

Fig. 3. Representative HPLC chromatogram for: a) blank rat plasma, b) blank plasma spiked with internal standard (IS).

Sensitivity. - LOD and LLOQ were 0.003 and $0.01 \mu \mathrm{g} \mathrm{mL} \mathrm{L}^{-1}$, resp., for both 7-hydroxywarfarin and warfarin (Table II). The method was found appropriate with RSD and $e_{\mathrm{r}}$ values at $L L O Q$ equal to $4.0-9.7 \%$ and $19.0 \%$, resp., for warfarin, and $2.2-8.2 \%$ and $19.0 \%$ resp., for 7-hydroxywarfarin (Tables III and IV).

Selectivity. - No endogenous interference from rat plasma was observed at the retention time for warfarin ( $\left.t_{\mathrm{R}} 14.2 \mathrm{~min}\right)$, 7-hydroxywarfarin $\left(t_{\mathrm{R}} 9.8 \mathrm{~min}\right)$, and IS ( $\left.t_{\mathrm{R}} 11.8 \mathrm{~min}\right)$ (Fig. 3). The method was able to distinguish warfarin and 7-hydroxywarfarin from other metabolites (Fig. 2). These results demonstrate that the method has the required selectivity to quantify warfarin and 7-hydroxywarfarin in rat plasma.

Carryover. - No analyte or internal standard peaks were observed in the blank samples injected following the highest standard concentration.

\section{Application to the pharmacokinetic study}

The validated HPLC-FLD method was applied successfully for simultaneous determination of warfarin and 7-hydroxywarfarin in plasma samples obtained from rats following 


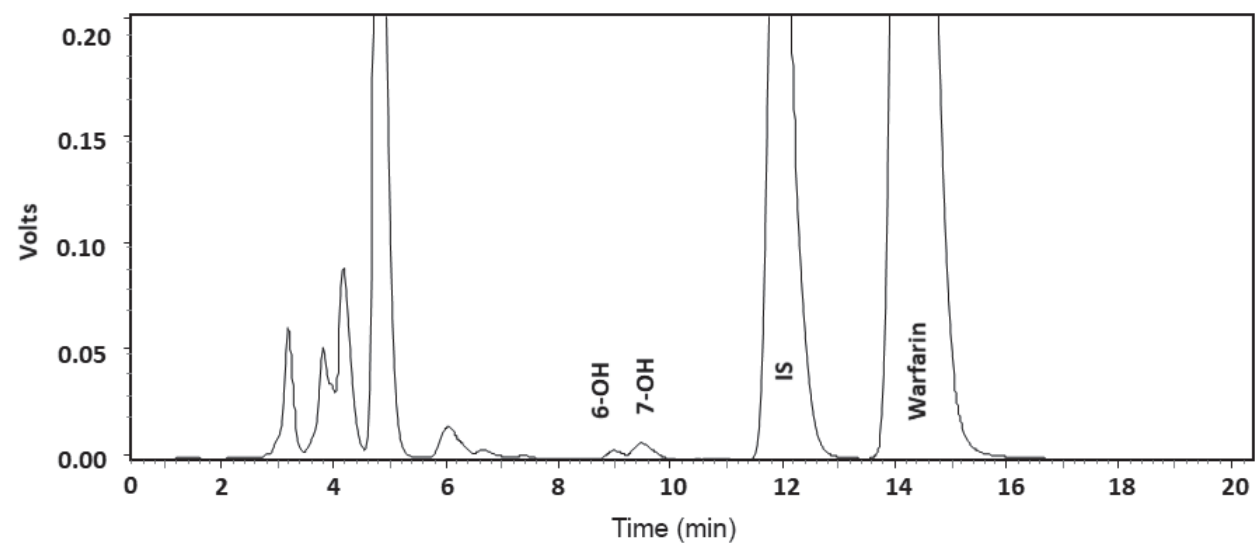

Fig. 4. Representative HPLC chromatogram for warfarin, 7-hydroxywarfarin and internal standard in real plasma sample obtained $24 \mathrm{~h}$ after single oral administration of $2 \mathrm{mg} \mathrm{kg}^{-1}$ warfarin. Keys to the peaks: 6-OH - 6-hydroxywarfarin, 7-OH - 7-hydroxywarfarin, IS - internal standard (naproxen).

oral administration of single warfarin dose. Representative chromatogram for a plasma sample collected $24 \mathrm{~h}$ post warfarin administration, is shown in Fig. 4. The chromatogram demonstrates the selectivity and sensitivity of the method to analyze real samples and its suitability for performing PK studies of warfarin and 7-hydroxywarfarin in rats. Plasma concentration vs. time profiles of warfarin and 7-hydroxywarfarin after oral administration of $2.0 \mathrm{mg} \mathrm{kg}^{-1}$ of warfarin is shown in Fig. 5, and the main PK parameters are outlined in Table V.

It was shown that $C_{\max }$ of warfarin metabolite, 7-hydroxywarfarin, was about $2.3 \%$ of respective $C_{\max }$ of warfarin, with the lower rate of formation/appearance in the systemic

Table V. Pharmacokinetic parameters of warfarin and

7-hydroxywarfarin after single oral administration of warfarin in SD rats ${ }^{a}$

\begin{tabular}{lcc}
\hline Pharmacokinetic parameter & Warfarin $^{\mathrm{b}}$ & 7-Hydroxywarfarin \\
\hline$C_{\max }\left(\mu \mathrm{g} \mathrm{mL}^{-1}\right)$ & $16.0 \pm 2.4$ & $0.36 \pm 0.06$ \\
$t_{\max }(\mathrm{h})$ & $3.0 \pm 0.6$ & $7.0 \pm 0.7$ \\
$A U C_{0}^{\infty}\left(\mu \mathrm{g} \mathrm{mL}^{-1}\right)$ & $378.4 \pm 66.6$ & $10.3 \pm 1.8$ \\
$A U M C_{0}^{\infty}\left(\mu \mathrm{g} \mathrm{h}^{2} \mathrm{~mL}^{-1}\right)$ & $10236 \pm 2770$ & $345 \pm 87$ \\
$M R T(\mathrm{~h})$ & $27.0 \pm 5.0$ & $33.0 \pm 4.0$ \\
$\mathrm{CL} / \mathrm{F}\left(\mathrm{mL} \mathrm{h}^{-1} \mathrm{~kg}^{-1}\right)$ & $6.0 \pm 0.9$ & $223.0 \pm 35.0$ \\
$V_{\mathrm{d}} / \mathrm{F}\left(\mathrm{mL} \mathrm{kg}^{-1}\right)$ & $292.0 \pm 64.0$ & $6409.0 \pm 1832.0$ \\
$t_{1 / 2}(\mathrm{~h})$ & $32.5 \pm 5.0$ & $21.0 \pm 6.0$ \\
\hline
\end{tabular}

a Dose of warfarin: $2 \mathrm{mg} \mathrm{kg}^{-1}$.

${ }^{\mathrm{b}}$ Mean $\pm \operatorname{SEM}(n=6)$. 
a)

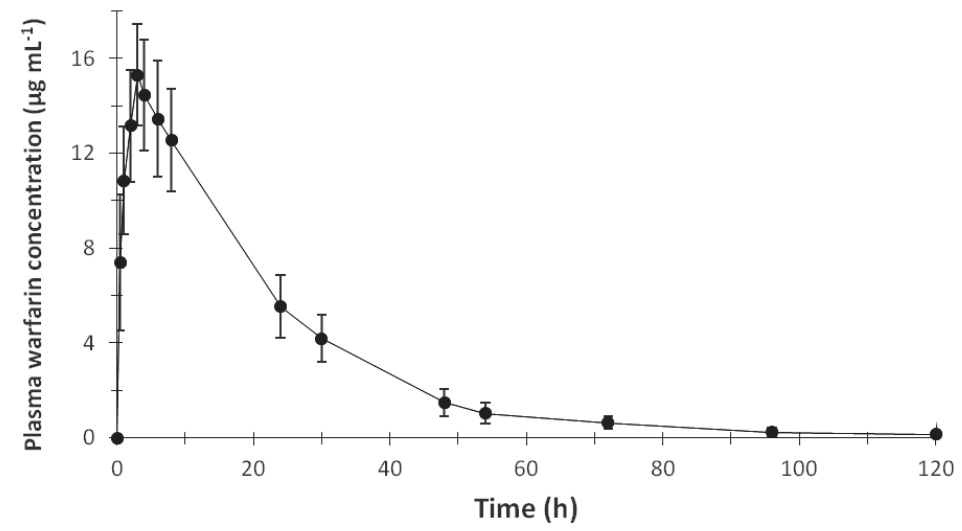

b)

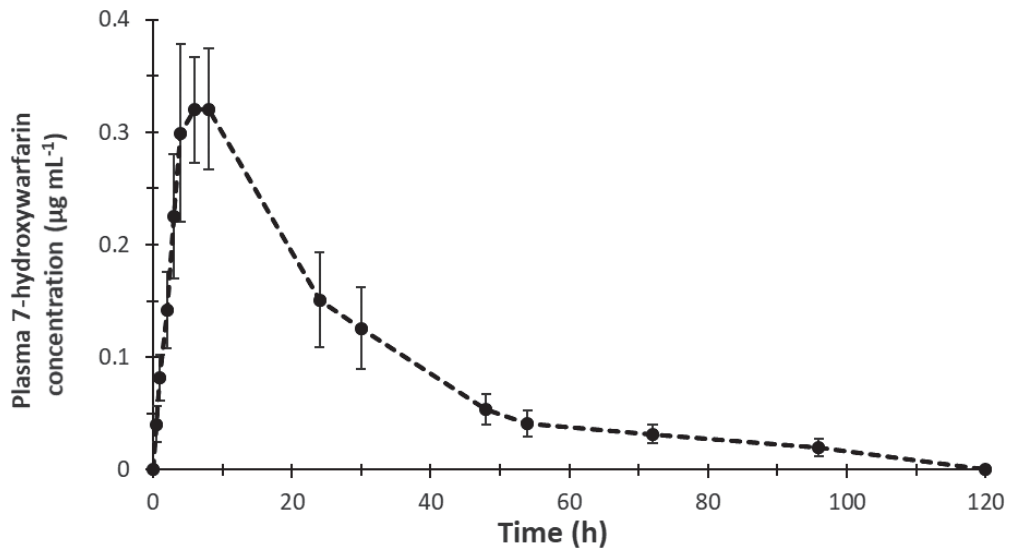

Fig. 5. Plasma concentration vs. time profiles of: a) warfarin, b) 7-hydroxywarfarin, following administration of a single oral dose of warfarin $\left(2 \mathrm{mg} \mathrm{kg}^{-1}\right)$. Mean \pm SEM $(n=6)$.

circulation. This was indicated by $\mathrm{ca} 4$-h increase in $t_{\max }$ compared to warfarin. The extent of warfarin bioavailability, represented by $A U C_{0}^{\infty}$, was shown to be 38-fold higher than that of its metabolite. Shorter terminal $t_{1 / 2}$ and higher apparent clearance was shown for 7-hydroxywarfarin, which resulted in the 21.9-fold larger apparent volume of distribution when compared to warfarin. These PK results are in agreement with reported PK results for warfarin and 7-hydroxywarfarin in rats (30) and demonstrate the reliability of the HPLC-FLD method for studying PK and metabolism of warfarin in rats.

Comparison of the described method with literature methods (Table VI) highlights the advantage of direct and simultaneous determination of warfarin and 7-hydroxywarfarin without the need for post-column manipulation or laborious sample derivatization which was required by previously published HPLC-FLD methods (28). The simplicity of liquid extraction combined with the isocratic reversed-phase conditions as opposed to normal phase (28), ion pair (27) or gradient elution (25) allows the method to lend itself readily to routine sample analysis such as in pharmacokinetic and animal studies. Moreover, the 


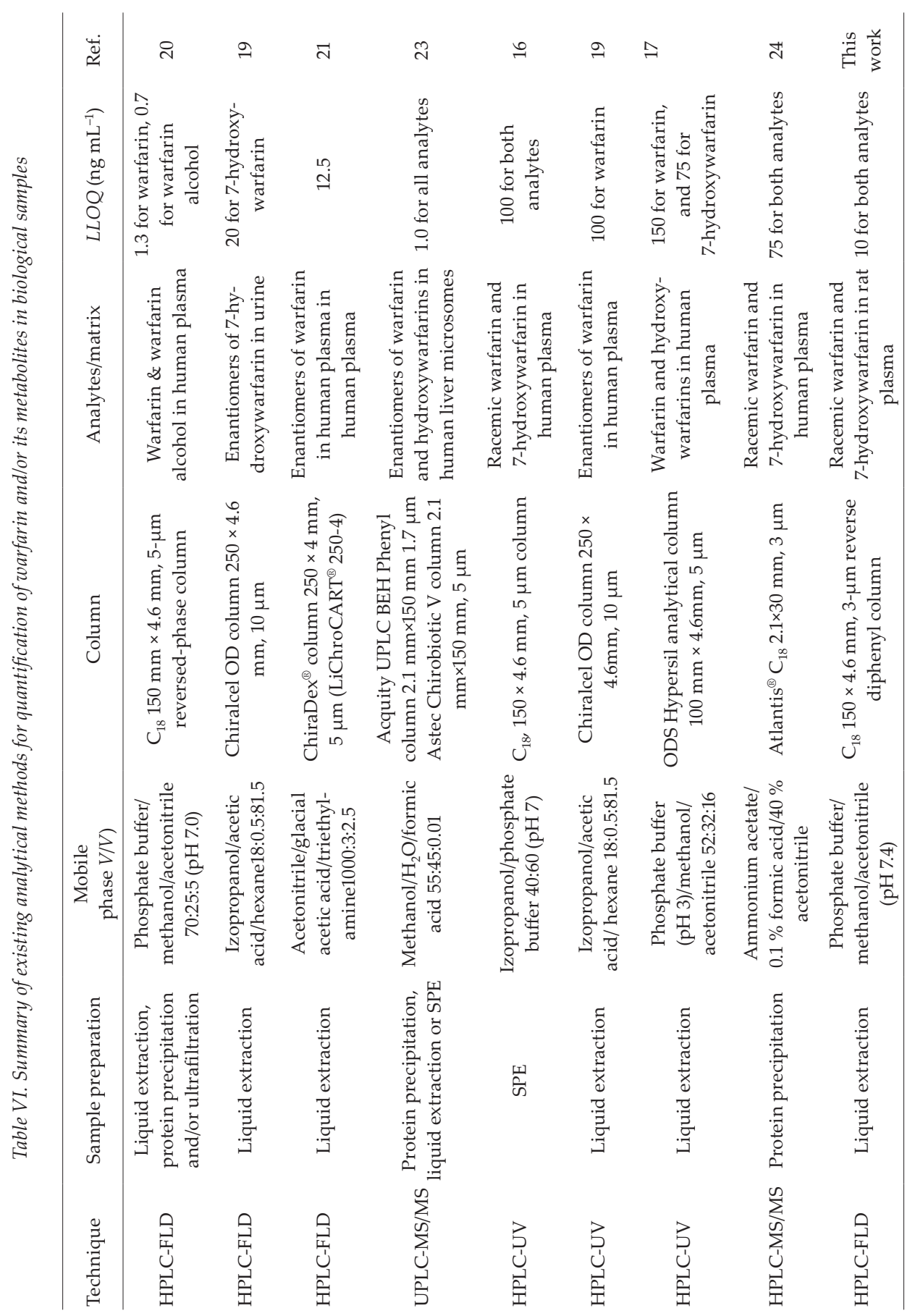


economy, sensitivity and selectivity of the FLD detection make this method ideal for quantifying warfarin and 7-hydroxywarfarin in complex matrices compared to the less sensitive UV $(16,17,19)$ and expensive MS detectors (23-25).

\section{CONCLUSIONS}

A new sensitive, selective, accurate and precise HPLC-FLD method has been developed and validated for the quantitation of warfarin and 7-hydroxywarfarin in rat plasma. The method demonstrated adequate sensitivity to quantify $0.01 \mu \mathrm{g} \mathrm{mL} \mathrm{m}^{-1}$ of both warfarin and 7-hydroxywarfarin in only $100 \mu \mathrm{L}$ plasma. The sensitivity and low instrument capital cost of the fluorescence detector combined with the unique selectivity of the diphenyl stationary phase make the method ideal for carrying out metabolic interaction studies of warfarin in small animals like rats. Quantification of 7-hydroxywarfarin will enable drug-to-drug and drug-to-diet interaction studies investigating altered warfarin metabolism and response because of various CYP2C9 phenotypes.

Acknowledgements. - This work was financially supported by Deanship of Scientific Research, Jordan University of Science and Technology, Irbid (Grant number 335/2017). The authors would like to extend their appreciation to German Academic Exchange Service (DAAD) for financially supporting W. B. during his MSc studies.

\section{REFERENCES}

1. A. M. Holbrook, J. A. Pereira, R. Labiris, H. McDonald, J. D. Douketis, M. Crowther and P. S. Wells, Systematic overview of warfarin and its drug and food interactions, Arch. Intern. Med. 165 (2005) 1095-1106; https://jamanetwork.com/journals/jamainternalmedicine/fullarticle/486574

2. M. Wadelius, L. Chen, K. Downes, J. Ghori, S. Hunt, N. Eriksson, O. Wallerman, H. Melhus, C. Wadelius and D. Bentley, Common VKORC1 and GGCX polymorphisms associated with warfarin dose, Pharmacogen. J. 5 (2005) 262-270; https://doi.org/10.1038/sj.tpj.6500313

3. N. H. Holford, Clinical pharmacokinetics and pharmacodynamics of warfarin, Clin. Pharmacokinet. 11 (1986) 483-504; https://doi.org/10.2165/00003088-198611060-00005

4. J. G. Kelly and K. O'Malley, Clinical pharmacokinetics of oral anticoagulants, Clin. Pharmacokinet. 4 (1979) 1-15; https://doi.org/10.2165/00003088-197904010-00001

5. A. Osman, C. Enström and T. L. Lindahl, Plasma S/R ratio of warfarin co-varies with VKORC1 haplotype, Arch. Intern. Med. 18 (2007) 293-296; https://doi.org/10.1097/MBC.0b013e3280444bfd

6. Bristol-Myers Squibb, Coumadin, 2006; http://www.accessdata.fda.gov/drugsatfda_docs/label/2006/ 021588s009lbl.pdf; last access date November 10, 2018.

7. R. A. O'Reilly, Warfarin Metabolism and Drug-drug Interactions, in The New Dimensions of Warfarin Prophylaxis (Eds. S. Wessler, C. G. Becker and Y. Nemerson), Springer, Boston (MA) 1987, pp. 205212.

8. C. Guo, S. Xue, X. Zheng, Y. Lu, D. Zhao, X. Chen and N. Li, The effect of fenofibric acid on the pharmacokinetics and pharmacodynamics of warfarin in rats, Xenobiotica 48 (2017) 400-406; https://doi.org/10.1080/00498254.2017.1306760

9. L. S. Kaminsky and Z.-Y. Zhang, Human P450 metabolism of warfarin, Pharmacol. Ther. 73 (1997) 67-74; https://doi.org/10.1016/S0163-7258(96)00140-4 
A. Zayed et al.: Simultaneous determination of warfarin and 7-hydroxywarfarin in rat plasma by HPLC-FLD, Acta Pharm. 70 (2020) 343-357.

10. M. Ufer, Comparative pharmacokinetics of vitamin K antagonists, Clin. Pharmacokinet. 44 (2005) 1227-1246; https://doi.org/10.2165/00003088-200544120-00003

11. M. Ufer, B. Kammerer, J. Kirchheiner, A. Rane and J.-O. Svensson, Determination of phenprocoumon, warfarin and their monohydroxylated metabolites in human plasma and urine by liquid chromatography-mass spectrometry after solid-phase extraction, J. Chromatogr. B 809 (2004) 217226; https://doi.org/10.1016/j.jchromb.2004.06.023

12. Q. Zhou, W. P. Yau and E. Chan, Enantioseparation of warfarin and its metabolites by capillary zone electrophoresis, Electrophoresis 24 (2003) 2617-2626; https://doi.org/10.1002/elps.200305441

13. Z. Zuo, S. K. Wo, C. M. Y. Lo, L. Zhou, G. Cheng and J. H. S. You, Simultaneous measurement of S-warfarin, R-warfarin, S-7-hydroxywarfarin and R-7-hydroxywarfarin in human plasma by liquid chromatography-tandem mass spectrometry, J. Pharm. Biomed. Anal. 52 (2010) 305-310; https:// doi.org/10.1016/j.jpba.2010.01.005

14. L. D. Heimark, L. Wienkers, K. Kunze, M. Gibaldi, A. C. Eddy, W. F. Trager, R. A. O’Reilly and D. A. Goulart, The mechanism of the interaction between amiodarone and warfarin in humans, Clin. Pharmacol. Ther. 51 (1992) 398-407; https://doi.org/10.1038/clpt.1992.39

15. A. H. Salem, B. Hu, K. J. Freise, S. K. Agarwal, D. S. Sidhu and S. L. Wong, Evaluation of the pharmacokinetic interaction between venetoclax, a selective BCL-2 Inhibitor, and warfarin in healthy volunteers, Clin. Drug Invest. 37 (2017) 303-309; https://doi.org/10.1007/s40261-016-0485-9

16. D. K. Kumar, D. G. Shewade, S. Parasuraman, S. Rajan, J. Balachander, B. V. S. Chandran and C. Adithan, Estimation of plasma levels of warfarin and 7-hydroxy warfarin by high performance liquid chromatography in patients receiving warfarin therapy, J. Young Pharm. 5 (2013) 13-17; https://doi.org/10.1016/j.jyp.2013.02.001

17. I. Locatelli, V. Kmetec, A. Mrhar and I. Grabnar, Determination of warfarin enantiomers and hydroxylated metabolites in human blood plasma by liquid chromatography with achiral and chiral separation, J. Chromatogr. B 818 (2005) 191-198; https://doi.org/10.1016/j.jchromb.2004.12.024

18. W. Naidong and J. W. Lee, Development and validation of a high-performance liquid chromatographic method for the quantitation of warfarin enantiomers in human plasma, J. Pharm. Biomed. Anal. 11 (1993) 785-792; https://doi.org/10.1016/0731-7085(93)80070-H

19. H. Takahashi, T. Kashima, S. Kimura, N. Muramoto, H. Nakahata, S. Kubo, Y. Shimoyama, M. Kajiwara and H. Echizen, Determination of unbound warfarin enantiomers in human plasma and 7-hydroxywarfarin in human urine by chiral stationary-phase liquid chromatography with ultraviolet or fluorescence and on-line circular dichroism detection, J. Chromatogr. B 701 (1997) 71-80; https://doi.org/10.1016/S0378-4347(97)00346-0

20. T. Lomonaco, S. Ghimenti, I. Piga, M. Onor, B. Melai, R. Fuoco and F. Di Francesco, Determination of total and unbound warfarin and warfarin alcohols in human plasma by high performance liquid chromatography with fluorescence detection, J. Chromatogr. A 1314 (2013) 54-62; https://doi. org/10.1016/j.chroma.2013.08.091

21. A. Qayyum, M. H. Najmi, A. M. Khan, M. Abbas, A. K. Naveed and A. Jameel, Determination of S-and R-warfarin enantiomers by using modified HPLC method, Pak. J. Pharm. Sci. 28 (2015) 13151321.

22. C. Huang, J. Yang, Y. Du and L. Miao, Measurement of free concentrations of highly proteinbound warfarin in plasma by ultra performance liquid chromatography-tandem mass spectrometry and its correlation with the international normalized ratio, Clin. Chim. Acta 393 (2008) 85-89; https://doi.org/10.1016/j.cca.2008.03.008

23. D. R. Jones, G. Boysen and G. P. Miller, Novel multi-mode ultra performance liquid chromatography-tandem mass spectrometry assay for profiling enantiomeric hydroxywarfarins and warfarin in human plasma, J. Chromatogr. B 879 (2011) 1056-1062; https://doi.org/10.1016/j.jchromb.2011.03.022 
24. M.-J. Kwon, H.-J. Kim, J.-W. Kim, K.-H. Lee, K.-H. Sohn, H.-J. Cho, Y.-K. On, J.-S. Kim and S.-Y. Lee, Determination of plasma warfarin concentrations in Korean patients and its potential for clinical application, Korean J. Lab. Med. 29 (2009) 515-523; https://doi.org/10.3343/kjlm.2009.29.6.515

25. A. N. Shaik, R. Grater, M. Lulla, D. A. Williams, L. L. Gan, T. Bohnert and B. W. LeDuc, Comparison of enzyme kinetics of warfarin analyzed by LC-MS/MS QTrap and differential mobility spectrometry, J. Chromatogr. B 1008 (2016) 164-173; https://doi.org/10.1016/j.jchromb.2015.11.036

26. Z.-Y. Zhang, B. M. King and Y. N. Wong, Quantitative liquid chromatography/mass spectrometry/ mass spectrometry warfarin assay for in vitro cytochrome P450 studies, Anal. Biochem. 298 (2001) 40-49; https://doi.org/10.1006/abio.2001.5383

27. Y. Wong and P. Davis, Analysis of warfarin and its metabolites by reversed-phase ion-pair liquid chromatography with fluorescence detection, J. Chromatogr. A 469 (1989) 281-291; https://doi. org/10.1016/S0021-9673(01)96463-5

28. S. H. Lee, L. Field, W. N. Howald and W. F. Trager, High-performance liquid chromatography separation and fluorescence detection of warfarin and its metabolites by postcolumn acid/base manipulation, Anal. Chem. 53 (1981) 467-471; https://doi.org/10.1021/ac00226a019

29. U. S. Department of Health and Human Services, Food and Drug Administration, Center for Drug Evaluation and Research (CDER) and Center for Veterinary Medicine (CVM), FDA Guidance: Guidance for Industry. Bioanalytical Method Validation, May 2018; http://www.fda.gov/downloads/drugs/ guidancecomplianceregulatoryinformation/guidances/ucm368107.pdf; last access date June 15, 2018.

30. C. Guo, S. Xue, X. Zheng, Y. Lu, D. Zhao, X. Chen and N. Li, The effect of fenofibric acid on the pharmacokinetics and pharmacodynamics of warfarin in rats, Xenobiotica 48 (2018) 400-406; https://doi.org/10.1080/00498254.2017.1306760 